\title{
Modeling mangrove 'blue carbon' ecosystem service in Jakarta bayas an impact of coastal development
}

\author{
Nasir Sudirman ${ }^{1,3}$, Muhammad Helmi ${ }^{2}$, dan Novi Susetyo Adi ${ }^{3}$ \\ ${ }^{1}$ Magister Program of Environmetal Science, School of Postgraduate Studies, Diponegoro University, Semarang - Indonesia \\ ${ }^{2}$ Department of Marine Science, Faculty of Fisheries and Marine Science, Diponegoro University, Semarang - indonesia \\ ${ }^{3}$ Marine Research Center, Research and Human Resources Agency For Marine And Fisheries Ministry of Marine Affairs and \\ Fisheries Republic of Indonesia
}

\begin{abstract}
Coastal ecosystems provide various ecosystem services in the form of natural resources, life support services, aesthetical values and comfort.The key ecosystems providing those services include estuaries, mangroves, coral reefs and seagrass beds.Some ecosystem services provided by the key coastal ecosystems function as producers, life supporters, wave absorbers, litter provider for detritus and decomposers, and carbon cycles regulator in the ecosystem. Though their roles are vital for Jakarta bay and its surrounding areas, ecosystem service aspect in Jakarta Bay is understudied. The previous limited studies focused mostly on economics valuation aspect and descriptive studies, ignoring the modeling and mapping aspects of the ecosystem services. InVEST (Integrated Valuation of Ecosystem Services and Tradeoffs) is a tool to map and model ecosystem services in an explicitly spatial representation.InVEST can be used to map and model changes in ecosystem servicess that will be affected by multi-scalechanges in the Jakarta Bay, particularlyland reclamation and what's so called as the Giant Sea Wall.The output generated through the spatial and temporal mapmodeling in inVESTcan account for ecosystem services in past, presentand future scenarios. In the context of various coastal development in Jakarta bay, the results of InVEST can be then be used asvaluableinput tocoastal management of Jakarta Bay, e.g. for mangrove management as a blue carbon ecosystem service provider.
\end{abstract}

Keywords:Blue Carbon; Reclamation; Giant sea wall; INVEST; Jakarta Bay

\section{Introduction}

Coastal is a confluence between teresterial and ocean. Ecosystem service providers in the form of natural resources, life support services and comfort. Ecosystem services are the contributions of various interrelated ecological structures and functions.Coastal ecosystem services include estuarine, mangroves, coral reefs, seagrass beds and small islands, which are interconnected in providing ecosystem services as producers in the food chain, supporting organism such as nursery ground, feeding ground, and spawning ground. Mangrove and seagrass ecosystems provide ecosystem services as absorbent waves that prevents abrasion, produces litter for detritus and decomposers, and organisms capable of maintaining carbon cycles in the ecosystem. Ecosystem services have been studied from the economic valuation aspect and descriptive depictions, modeling and mapping of ecosystem services has not been done.

Outputs from modeling generated from spatial and temporal maps that can be used as input for sustainable management, optimization in area planning, environmental protection, natural conservation and recovery, natural-based solutions, climate protection, disaster risk reduction, environmental education and research with various scenarios desired by stakeholders.

Population growth and the increase of life activity in Jakarta caused the higher land demand. The problem of land subsidence accompanied by sea level rise causedflood in the North Jakarta area. Land needs are responded by the government through reclamation, while the tidal flood and to slow the land subsidance through the construction of Giant sea wall.

Jakarta as a national strategic area which is the central government as well as a province that has the authority to regulate. The authority that cuts between national and regional often becomes the polemic of one of the reclamation and giant sea wall in Jakarta Bay. To harmonize coastal reclamation and sea giant sea wall, the government seeks to integrate it into a National Capital Integrated Coastal Development (NCICD)

The rapid development of coastal areas of Jakarta Bay is not accompanied by mapping efforts of ecosystem services in full based chronologically following the development of the region. Ecosystem service mapping efforts can be done through spatial modeling of Integrated Valuation Of Ecosystem Services And Tradeoffs (InVEST). This modeling is used to map and model changes in ecosystem services with various planned change that will occur in Jakarta Bay, especially mangrove ecosystem modeling as a blue carbonproducing ecosystem service which is the goal of this research. Benefits generally provide spatial and temporal information as inputs for regional development, specifically to identify coastal ecosystem services mangroves as regulators of carbon cycle.

The benefit of this study is that it can provide spatial and temporal information on coastal blue carbon ecosystem services as a basis for calculating compensation for development damage, knowing future ecosystem services that will be affected, input in coastal

\footnotetext{
*Corresponding author: nasir sudirman nsr.sudirman@gmail.com
} 
area development planning so that there is a balance between development needs and sustainability of blue carbon ecosystem services

\section{Literature Riview}

\subsection{Coastal Area of Jakarta Bay}

The coastal area is an interface areawhere all types of processes occur depending on terrestrial and marine interactions [1], are transitions from freshwater and marine ecosystems with high natural resource potential [2].The bay is the sea that juts into the mainland, has a clear curve, proportional to the width of its mouth to form a closed water, the curve has a semicircular area with the diameter of the line drawn across the mouth of the indentation [3].

The north coast of Jakarta has a length $32 \mathrm{Km}$. Jakarta bay in 5000 years ago is tectonic height area, with coastline in Monas area at present. This altitude is motivated by the eruption of Mount Salak which emits material and forms an alluvium fan-shaped sediment which then forms a lowland that's starts from Monas to the north. The soil increases 15 meters each year due to sedimentation, especially in 13 river estuaries, including Cisadane in the west and the Citarum river to the east [4]. Sedimentation result carried by rivers creates a delta with topography of mud and sand [5].

\subsection{Development Plan of Jakarta Bay}

Jakarta is a national strategic area in accordance with Government Regulation (PP) No.26 of 2008 in which the spatial arrangement is prioritized. The determination was upheld by Presidential Decree (PERPRES) No. 54 of 2008. Development of the Jakarta Bay area to resolveenvironmental degradation, resource requirements, land and space.Based on Constitution (UU) No. 32 of 2009 concerning the protection and management, explains the importance of determining the carrying capacity for resource use and the environment does not occur Over Capacity. Guidelines for determining the carrying capacity of regional spatial arrangements are set out in Ministerial Regulation (PERMEN) Ministry Of Environment And Forestry No.17 Of 2009.

\subsubsection{Reclamation of Jakarta Bay}

Reclamation is an activity carried out by everyone to increase the benefits of land resources in terms of the environmental and socio-economic conditions bylandfilling,draining (UU) No.1 of 2014concerning the Management of Coastal Areas and Small Islands. The earlyidea of reclamation emerged in 1995 through (KEPRES) No.52 of 1995.

The provisions of reclamation are contained in (PERDA) No.1 of 2012 on spatial planning and territory (RTRW) 2030 and governor regulation (PERGUB) No.121 of 2012. Detailed plan for reclamation is outlined in regional regulation (PERDA) No.1 of 2014 conceringspatial detail plan (RDTR) and Zoning Regulation [6]. In PERGUB No.121 of 2012 mentioned there are 17 islands named Island A to Island Q with a total area of 5,155 hectares and the issuance of principle licenses for Islands F, G, I and K. In the Year 2014-2015 is issued implementation licensefor Island G, F, H, I, and $\mathrm{K}$ [7].

Reclamation efforts to meet the needs of the land received various rejections, because based on studies showing reclamation will have an impact on changes in natural ecosystems that cause problems of pollution, sedimentation due to changes in current patterns, and the problems of coastal communities that depend on Jakarta Bay.One of the refusals was made by the Ministry of marine and fisheries who asked the DKI government to stop reclamation due to the central government's authority that occurred since 2014 but was ignored. In 2016 the KPK captures members of the DKI Jakarta Provincial Legislative Assembly and the developer with allegations of bribery related to two RAPERDA reclamation, due to the case, the DPRD DKI did not continue the discussion because there is no clarity from the central government related to the continuation of strategic environmental studies (KLHS)to covering two regional regulation draft (RAPERDA) zoning plans for coastal areas and small island (RZWP3K) and RAPERDA Spatial Plan of Strategic Area of North Coast of Jakarta (RTTKS Pantura) [8]

In 2017 the ministry of maritime coordinators revoked the reclamation moratorium, based on the lifting of administrative sanctions on C, D and G islands, as it has met environmental impact analysis (AMDAL) by the environment and forestry ministries, on the basis of the revocation of the Ministry of maritime coordinator issued Decree No.S-78001/02 / Menko / Maritime / X / 2017 to revoke the moratorium on reclamation of the island [9].

\subsubsection{Giant sea wall in national capital integrated coastal development (NCICD) \\ The objective of NCICD is to protect Jakarta} against flood threats and slowdown of land subsidence through the construction of giant sea wall.In 1990, only $12 \%$ or 1,600 ha of northern land of Jakarta was below sea level, estimated that by 2030 nearly $90 \%$ or 12,500 ha of the northern coastline of Jakarta would be drowned (PTPIN, Coordinatingministry economic affairs, 2014 in [10]. Jakarta is experiencing3-18 cm/year land subsidence, if left untreated, river water can not flowgravity into the sea and sea water will flood Jakarta $[10]^{2}$ NCICD strived to integrate with coastal reclamation activities of Jakarta Bay, which is expected to improve the environmental quality and realize the strategic area of Pantura Jakarta as a waterfront city $[10]^{3}$. The declaration was conducted in 2007 by the Government of DKI Jakarta in cooperation with the Netherlands, which will be done in 2009-2012. The reclamation plan is a partnership between the government and the developer, through a cross subsidy mechanism $[9]^{2}$. 
As per the presidential directive on April 27, 2016, NCICD does not cause problems as long as it meets 3 requirements:

a) Environmental Aspects, aspects related to marine biota, mangrove forest, and other environmental factors.

b) Legal / regulatory aspects, construction of NCICD to follow applicable rules and laws and strict supervision.

c) Social aspect, NCICD project to put forward the principle of benefit for the people, especially fishermen, not to be ignored or abandoned [10].

\subsection{Ecosystem Services in Jakarta Bay}

Ecosystem services in the bay area have a very important role in accordance with the characteristics of the bay itself. In general, Ecosystem services has 4 main functions for human life as life support services, convenience, natural resource providers, and recipients of waste [11]. Therefore, the use of ecosystem must be done carefully. Damage to one ecosystem can disturb the balance of other ecosystems so ecosystem management must be done in an integrated manner $[1]^{2}$. The ecosystem service approach is built on the premise that the entire ecosystem in the world is linked and not one ecosystem can function as a completely closed system. For assessing Ecosystem carrying capacity and capacity, [13] defines four basic categories of ecosystem services:

a) Provisioning; providing food, water, wood fiber, and fuel.

b) Regulating; regulate climate, water and flood, disease, water purification.

c) Cultural; providing aesthetic potential, ecotourism, and living space

d) Supporting; nutrient recycling, soil formation and primary production.

The measurement and mapping of ecosystem services will determine the accuracy resource management policy making. In the implementation of ecosystem service measurements constrained by inconsistent methods [13], as a result when there is damage caused by humans both individually and in groups, the government cannot claim losses caused by such destructive activities based on market value and not marketvalue.The important value of ecosystems besides can be done with the ecological approach also through economic valuation of each function of biotic and abiotic components [14], the value of mangrove ecosystem services is mostly done through direct and indirect benefits approach, among others, Suzana et.al.[15], Saprudin and Halidah [16]. Direct benefits include the value of wood as a building material and firewood, economic value of fishery (fish, shrimp, crabs), value of leaves and fruit of mangrove.

\subsection{Mangrove ecosystem in Jakarta Bay as a provider of coastal blue carbon services}

Mangrove have high ecological, economic and social value, mangrove is the main ecosystem supporting life in coastal and marine area $[16]^{2}$. Indonesia has a mangrove ecosystem based on satellite images imagery covering $3,112,989$ ha or $31,129.89 \mathrm{~km} 2$ which is $22.6 \%$ of the total mangrove area in the world [17]. Mangrove ecosystem has functions, namely [18]:

a) Physical functions include maintaining coastlines and river banks, accelerating land expansion, treating waste, reducing tsunami storms, buffering intrusion processes

b) Biological / ecological functions include the nesting place of birds, natural habitat, nursery, feeding, spawning ground and protection area

c) Economic functions include shelter ponds, salt making, recreation, wood and beams.

d) Chemical function produces $\mathrm{O} 2$ and absorbs $\mathrm{CO} 2$, industrial waste and shipboard processors

e) Socio-economic functions, fuel producers, raw materials, furnishings, cosmetics, food, textiles, adhesives, tanneries, fish, shrimp, shellfish, crabs, tourist, conservation, education and research

Mangrove ecosystems in Jakarta Bay include Muara Gembong Sub-district, Bekasi District, Teluk Naga District, Tanggerang Regency, and Penjaringan district of North Jakarta with 9,749ha. [2] $]^{2}$. The mangrove cover in Muara Angke and Muara Gembong is also very small, below $20 \%$. The diversity of flora and fauna also decreased, except for flora in Muara Angke, the addition of new non mangrove species. The mangrove ecosystem in Jakarta Bay has been degraded and deforested due to land conversion ponds [20].

Mangrove degradation is not only caused by the logging of individual areas as well as by the government through land conversion policies. Historically, the government has established mangrove area in Muara Angke reaching 1,344.62 ha in $1960 \mathrm{~s}$, through Decree of Minister of Forestry No.097/Kpts-II/88 covering 831,63 ha of mangrove forest area being released for residential and business areas. The remaining Mangrove in Muara Angke cover an area 327,70ha, but also experienced improvements by the Department of Marineaffairs and Agriculture, BKSDA DKI Jakarta, and PT Murindra Karya Lestari through the implementation of mangrove rehabilitation which hadpreviously been damaged or has changed the area ofaquaculture [20].

Based on Decree (SK) Minister of Forestry No.667/Kpts-II/1995 mangrove in Muara Gembong area of $327.70 \mathrm{ha}$ which was originally $10,480 \mathrm{ha}$, then Minister of Forestry Decree No.475/Menhut-II/2005 of 5.170 ha converted into permanent production forest which then converted again for the interests set by RTRW of Bekasi Regency, Muara Gembong mangrove covering 10,481,15ha, in the form of protected forest and production forest managed by Perum Perhutani. As a key player of the Bekasi District Government and the community runs the Joint Forest Management Program in collaboration with Perhutani based on Agreement No.95 / EK / SPK / EK / 28.26.3 / VII / 1985 and No.09.7 / BGR / III 1985 concerning Security Cooperation, Conservation and Utilization of Mangrove Forest in the North Coast of Bekasi Regency [19].

Mangroves and seagrasses are an important part of the carbon cycle in the waters. The role of mangroves in utilizing $\mathrm{CO} 2$ for the photosynthesis process and storing 
it in biomass and sediment stocks as an effort to mitigate climate change [20]. Carbon storage in mangrove ecosystems begins to get attention as one of the ecosystem services that play a role in mitigating climate change [21] [22] [23] [24]. The importance of mangrove ecosystems is not always directly proportional to the condition of the ecosystem on the coast. The population growth with high economic activity is a threat to the mangrove ecosystem. The level of mangrove degradation during the half century reached $30-50 \%$ where the loss of mangrove ecosystems was due to large-scale land conversion for aquaculture, coastal city development or logging [25]. Global mangrove deforestation and land use change can cause carbon dioxide (CO2) emissions of about $10 \%$ or equivalent to $0.02-0.12 \mathrm{Pg} \mathrm{C}$ per year [25]

\section{Methods}

\subsection{Modeling integrated valuation of ecosystem services and tradeoffs (InVEST)}

InVEST modeling is a software used to map, calculate, and assess ecosystem services, a flexible and scientific model. This modeling focuses on ecosystem services, spatially, providing biophysical, market and non-market outputs, based on planning, demonstrating the relationship between diverse ecosystem services, modular and tiered approaches to accommodate data availability and knowledge system tiers [26]. InVEST as a tool to support ArcGIS Geographic Information System (Environmental Systems Research Institute, 2011). Users can combine and match Tiers 0,1 , and 2 models for some ecosystem services to create the best set of models for a particular context. InVEST which previously contained only terrestrial and freshwater models to include models of marine and coastal systems [27]. Alternative scenarios for marine InVEST typically include future coastal and marine land use maps, coastal and marine habitats, and future forecasts of climatic conditions.

InVEST marine modeling includes renewable energy (Tier 1), food from fisheries (Tiers 0 and 1) and aquaculture (Tier 1), coastal protection (Tier 0 and 1), aesthetic landscapes (Tier 0 ), recreation (Tier 0 and 1 ), and carbon sequestration and sequestration (Tier 1) $[26]^{2}$. Marine InVEST also currently includes two models of support services that take into account the ecological relationship between processes that result in changes in ecosystem services such as water quality (Tiers 0 and 1) and habitat risk assessment (Tier 0). An important component of marine InVEST is its ability to link service models to represent how a single service change can affect other services.

\subsection{Modeling of mangrove ecosystem in jakarta bay as a coastal blue carbon services}

Jakarta Bay is the object of research is a region that will experience a very big change due to the development of coastal areas, namely the construction of 17 artificial islands through reclamation and construction of Giant Sea Wall which is integrated as an (NCICD).
The reclamation activity that was stalled, now resumed and has resulted in several islands in Jakarta Bay, GSW will be built to overcome the coastal problems of the capital area although the conflict still exists. To increase the knowledge and as input for the government.

INVEST modeling is the method that will be used in this research. Temporal modeling that will be done on the coastal area of Jakarta Bay is divided into three stages:

a) Modeling conditions prior to reclamation and Giant sea wall. This model aims to know and calculate services in the past.

b) Recent condition modeling based on the reclamation that has been done. This model aims to find out and calculate the current ecosystem services where reclamation has resulted in several islands in Jakarta Bay.

c) The modeling of the future condition of Jakarta Bay based on the modeling when reclamation and GSW have been fully formed. This model aims to identify and quantify ecosystem services in the future.

Mangroves and seagrasses store carbon in the form of biomass and store it in sediment in large amounts of carbon in coastal areas. The development of coastal areas that convert vegetation cover by clearing seagrass and mangrove can change the carbon storage and absorption potential of the ecosystem. Sea carbon modeling at (Tier 1) estimates how much carbon is stored in coastal vegetation biomass, sediment, and economic valuation value from carbon storage and sequestration.

\section{Result And Discussion}

This research is still running at the running model stage.In this study will produce: 1. Carbon Stock Rasters (Units: Megatonnes CO2 e per Hectare), 2. Carbon Accumulation Rasters (Units: Megatonnes CO2 e per Hectare), 3. Carbon Emissions Rasters (Units: Megatonnes $\mathrm{CO} 2$ e per Hectare), 4. Net Carbon Sequestration Rasters (Units: Megatonnes CO2 e per Hectare), 5. Net Present Value Raster (Units: (Currency of Provided Price Table) per Hectare)

\section{Conclusions}

The conclusions obtained in this study are the mapping of the current coastal blue carbon ecosystem service conditions and the future conditions of coastal blue carbon ecosystem services based on regional development plans through spatial modeling

\section{References}

1. Asyiawati.Y., Yuliand.F., Dahuri. R., Sitorus.S.R.P., Susil.S.B. "Status Ekosistem Pesisir Bagi." 10(1): $1-7$.

2. Parawansa.I, 2007, Pengembangan Kebijakan Pembangunan Daerah dalam Pengelolaan Hutan 
Mangrove di Teluk Jakarta Secara Berkelanjutan, Tesis Sekolah Pascasarjana Institut Pertanian Bogor

3. UNCLOS, 1982

4. Lembaga Ilmu Pengetahuan Indonesia (LIPI), 2017, 5 Dekade LIPI di Teluk Jakarta Riview Penelitian Oseanografi di Teluk Jakarta 1970 - 2015, Jakarta, Lembaga Ilmu Pengetahuan Indonesia (LIPI)

5. Nuraini.S., Prihatiningsih., Wahyuningsih., Wejatmiko, 2011, Status pemanfaatan kekerangan di perairan Teluk Jakarta dan sekitar nya, [Buku] Sumberdaya ikan di perairan teluk Jakarta dan alternatif pengelolaanya, Jakarta, IPB Press

6. Kusumawati.T, 2016, Kebijakan pengembangan kawasan strategis provinsi pantai utara Jakarta, [Paparan tidak dipublikasikan disampaikan selaku Kepala Bappeda DKI Jakarta]

7. https://news.detik.com/berita/3045109/izinreklamasi -teluk-jakarta-diteken-foke-sebulan-sebelum-lengser di akses pada tanggal 26 April 2018

8. https://news.idntimes.com/indonesia/helmi/mengena 1-11-hal-reklamasi-jakarta-dari-soeharto-sampaianies-1/full di akses pada tanggal 26 April 2018

9. http://www.mongabay.co.id/2017/10/11/adakejanggalan-dalam-prosedur-pencabutanmoratorium-reklamasi-teluk-jakarta-seperti-apa/ di akses pada tanggal 26 April 2018

10. Kementerian Koordinator Bidang Perekonomian Pengembangan Terpadu Pesisir Ibukota Negara, 2014, Pengembangan Terpadu Ibukota Pesisir Ibukota Negara, [Buku] Pengembangan Terpadu Ibukota Pesisir Ibukota Negara

11. Bengen, Dietriech Geoffrey. 2000. "Pengelblmn Ekosistem." Pengelolaan Ekosistem Wilayah Pesisir: 61.

12. Millennium Ecosystem Assessment (MEA). 2005. Ecosystems and Human WellBeing: Synthesis, Island Press, Washington, USA

13. Crossman, Neville D. et al. 2013. "A Blueprint for Mapping and Modelling Ecosystem Services." Ecosystem Services 4(March): 4-14.

14. Kepel.T.L., Suryono.D.D., Ati.R.N.A., Salim.H.L., Hutahaean.A.A., 2017, Nilai penting dan estimasi nilai ekonomi simpanan karbon vegetasi mangrove di Kema Sulawesi Utara, Jurnal Kelautan Nasional Vol 12 No 1 Hal: $19-26$

15. Suzana, B. O. L., Timban, J., Kaunang, R., \& Ahmad, F. (2011). Valuasi Ekonomi Sumberdaya Hutan Mangrove di Desa Palaes Kecamatan Likupang Barat Kabupaten Minahasa Utara. ASE Vol. 7 No. 2: 29-38

16. Saprudin dan Halidah, 2012, Potensi dan Nilai Manfaat Layanan Lingkungan Hutan Mangrove di Kabupaten Sinjai Sulawesi Selatan, Jurnal Penelitian Hutan dan Konservasi Alam Vol 9 No 3 Hal: $213-219 p$

17. Giri, Chandra et al. 2015. "Distribution and Dynamics of Mangrove Forests of South Asia." Journal of Environmental Management 148: 10111.http://dx.doi.org/10.1016/j.jenvman.2014.01.020.

18. Saparinto, C., 2007. Pendayagunaan Ekosistem Mangrove Mengatasi Kerusakan Wilayah Pantai dan meminimalisasi Dampak Gelombang Tsunami. Effhar dan Dahara Prize. Semarang

19. Ambinari,M., Darusman.D., Alikodra.H.S., Santoso,N., 2016, Penataan Peran Para Pihak dalam Pengelolaan Hutan Mangrove di Perkotaan: Studi Kasus Pengelolaan Hutan Mangrove Di Teluk Jakarta, Jurnal Analisis Kebijakan Vol. 13 No.1 Hal: $29-40$

20. Afiati,R.N, Rustam,A., Kepel.T.L., Sudirman,N., Astrid,M., Daulat,A., Suryono,D.S., Puspitaningsih,Y., Mangindaan,P., Hutahaean,A., 2014, Karbon Stok Dan Struktur Komunitas Mangrove Sebagai Blue Carbon Di Tanjung Lesung, Banten, Jurnal Segara Vol. 10 No. 2, Hal: 119-127

21. Bouillon, S., Borges, A. V., Castaneda-Moya, E., Diele, K., Dittmar, T., \& Duke, N.C. (2008). Mangrove Production and Carbon Sinks: A Revision of Global Budget Estimates. Global Biogeochemical Cycles, 22(2).

22. Alongi, D.M. (2014). Carbon Cycling and Storage in Mangrove Forests. Annual Review of Marine Science, 6, pp.195-219.

23. Murdiyarso, D., Purbopuspito, J., Kauffman, J. B., Warren, M. W., Sasmito, S. D., Donato, D. C., Manuri, S., Krisnawati, H., Taberima, S., \& Kurnianto, S. (2015). The Potential of Indonesian Mangrove Forests for Global Climate Change Mitigation. Nature Climate Change, (July), pp.8-11.

24. Alongi, D. M., Murdiyarso, D., Fourqurean, J. W., Kauffman, J. B., Hutahaean, A., Crooks, S., Lovelock, C. E., Howard, J., Herr, D., Fortes, M., Pidgeon, E., \& Wagey, T. (2015). Indonesia's Blue Carbon: A Globally Signifcant and Vulnerable Sink for Seagrass and Mangrove Carbon. Wetlands Ecology and Management.

25. Donato, Daniel C. et al. 2011. "Mangroves among the Most Carbon-Rich Forests in the Tropics." Nature Geoscience 4(5): 293-97. http://dx.doi.org/10.1038/ngeo1123.

26. Tallis H, Polasky S. 2009. Mapping and valuing ecosystem services as an approach for conservation and natural-resource management. Ann N Y Acad Sci. 1162:265-283.

27. Guerry.A.D., Ruckelshaus.M.H., Arkema.K.K., Bernhardt.J.R., Guannel.G., Kim.C.K., Marsik.M., Popenfus.M., Toft.J.E., Verutes.G., Wood.S.A., Beck.M., Chan.F., Chan.Kai. M.A., Gelfenbaum.G., Gold.B.D., Halpern.M.McField., Pinsky.M.L., Plummer.M., Polasky.S., Ruggiero.P., Sutherland.D.A., Tallis.H., Day.A., Spencer.J, 2012, Modeling benefits from nature: using ecosystem services to inform coastal and marine spatial planning, International Journal of Biodiversity Science, Ecosystem Services \& Management, iFirst, $1-15$

28. Kareiva P, Tallis H, Ricketts T, Daily G, Polasky S, editors. 2011.Natural capital: theory and practice of mapping ecosystem services. Cambridge (UK): Oxford University Press. 